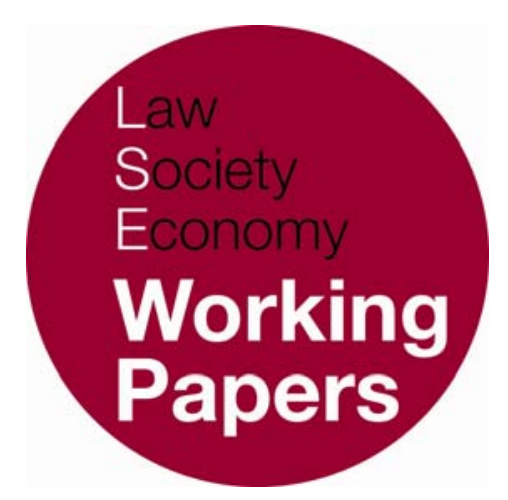

\title{
Involuntary Creditors and the Case for Accounting-Based Distribution Regulation
}

\author{
David Kershaw
}

LSE Law, Society and Economy Working Papers 16/2007

London School of Economics and Political Science

Law Department

\footnotetext{
This paper can be downloaded without charge from LSE Law, Society and Economy Working Papers at: www.lse.ac.uk/collections/law/wps/wps.htm and the Social Sciences Research Network electronic library at: http://ssrn.com/abstract $=1033325$.

(C) David Kershaw. Users may download and/or print one copy to facilitate their private study or for non-commercial research. Users may not engage in further distribution of this material or use it for any profit-making activities or any other form of commercial gain.
} 


\title{
Involuntary Creditors and the Case for Accounting-Based Distribution Regulation
}

\author{
David Kershaw*
}

\begin{abstract}
This article argues that accounting-based distribution regulation provides variable and at times significant protection to both existing involuntary creditors - by increasing the probability that they will be paid - and the constituency of involuntary creditors - by decreasing the probability that companies' actions will produce involuntary creditors. These benefits become visible when close attention is paid to the interaction of applicable accounting standards on the recognition of provisions with the UK's existing distribution regime. Whilst the current debate and reform consensus correctly analyses the relationship between the current regime and adjusting creditors, the article argues that the organising category of the 'capital maintenance doctrine' has obstructed inquiry into the ways in which the existing rules' dependence on accounting standards results in benefits for involuntary creditors.
\end{abstract}

\section{INTRODUCTION}

In UK legal academic and professional circles a consensus has recently emerged that the rules determining when companies may make distributions to shareholders are in need of reform. There are two primary divers of this reform consensus. The first is that the rules are unnecessary to guard their regulatory constituency, namely adjusting creditors, who care little for the rules and in any event are capable of protecting themselves. Through this lens, distribution rules prevent the company from opportunistically exploiting creditors by returning capital to shareholders following the incurrence of debt. However, as English law's minimum capital requirements are zero for private companies and insignificant for public companies the company may have limited capital for the distribution rules to prevent being returned. It follows, therefore, that only those creditors that can adjust their terms of trade to the actual capitalization of the firm can benefit from the distribution restrictions. If those creditors do not rely upon or view these rules as a useful protective device then the case for their continued application is weak. This article refers to this driver of reform as the 'constituency

\footnotetext{
* London School of Economics and Political Science. My thanks go to Julia Black, Marlies Braun, Harald Halbhuber, Alison Kershaw, Eva Micheler and Jonathan Rickford for comments on earlier versions of this paper. The usual disclaimer applies.
} 
driver'. The second objection and driver of reform is that the reliance of distribution regulation on accounting based tests means that changes in accounting standards may unintentionally distort capital markets by preventing financially healthy and solvent companies from issuing dividends. Affected companies may experience an increase in their cost of equity capital as their investor base shrinks because these companies are no longer attractive investment options for those investors who require regular dividends. This cost of capital increase is, it is argued, unnecessary. These distortions can be removed whilst at the same time protecting creditors' interests through an approach that would allow distributions where company directors certify the solvency of the company at the time of the distribution and for a period thereafter. This article refers to this driver of reform as the 'distortion driver'.

This article considers these two drivers of reform from the perspective of the involuntary, non-adjusting creditor. According to the constituency driver involuntary creditors are not protected by the distribution rules and therefore have nothing to lose through their reform. According to the distortion driver creditors, including involuntary creditors, are as well protected by the solvency certification approach. It follows, therefore, that involuntary creditors would be indifferent to reform that replaces the current regime with a solvency-based approach. In relation to the constituency driver, this article argues that involuntary creditors obtain distinct and tailored benefits from current distribution regulation. These benefits, the article argues, have been underweighted and unexplored as a result of a tendency in the literature to amalgamate regulatory function with effect. Although the rules were conceived as part of the capital maintenance doctrine and although the functional 'best fit' may well be to prevent opportunistic returns of capital to shareholders, in application the rules have had broader effects and have generated unintended constituencies. Following the identification of these benefits, the article considers the distortion driver and considers whether a solvency certification provides equivalent protection for involuntary creditors. It argues that on balance the solvency certification approach would diminish the identified protection provided to involuntary creditors under the current rules.

\section{THE CONSTITUENCY DRIVER}

\section{The Logic of Capital Maintenance}

English law has long had rules regulating when companies can make distributions of assets to their shareholders. Basil Yamey, writing in 1941, distinguished between pre-1889 and post-1889 case law. ${ }^{1}$ The former exemplified by $R e$

${ }^{1}$ B. Yamey, 'Aspects of the Law Relating to Company Dividends' (1941) MLR 273. 
Flitcrofts's Case ${ }^{2}$ required that a distribution could not be made out of capital which, strictly speaking, meant that the distribution could not result in an accounting reduction of the capital account ${ }^{3}$ to an amount below the legal capital entry. Legal capital ${ }^{4}$ at this time consisted of the aggregate nominal value of the issued shared. Yamey notes in this regard that 'company directors in the period before 1889 were confronted by a rigid rule forbidding any dividend payment which would have reduced the remaining assets below the figure of the company's nominal paid-up capital'. ${ }^{5}$ The 'reason' for this was stated by Jessel MR to be that:

There is a statement [in the memorandum of association] that capital shall be applied for the purposes of the business, and on the faith of that statement, which is sometimes said to be an implied contract with creditors, people dealing with the company give it credit. The creditor, therefore, I may say gives credit to that capital, gives credit to that company on the faith that the representation that the capital shall only be applied for the purposes of the business, and he has, therefore, a right to say that the corporation shall keep its capital and not return it to the shareholders, though it may be a right which he cannot enforce otherwise than by a winding up order.

For post-1889 case law, however, the criterion for making a distribution was merely the generation of profit. The questions of relevance became first, who was the arbiter of whether a profit had been made: the courts, directors or the accounting profession; and second, what was the time period within which profits had to be made. The case of Lee $v$ Neuchatel Asphalte Company ${ }^{6}$ and its progeny gave considerable deference to the board's determination of profit even where the approach taken was contrary to the accounting best practice of the time. This resulted in distributions being held to be legal where, for example, the profit calculation did not take account of depreciation in fixed asset values. ${ }^{7}$ Subsequent case law also held that profits generated in one financial year could be distributed even though, together with the results of previous financial years, the company had an accumulated loss. ${ }^{8}$ Both these types of distribution, although held to be legal, could result in a reduction in the capital account below the legal capital entry.

\footnotetext{
2 In re Exchange Banking Company (Flitcroft's Case) (1882) LR 21 Ch. D. 519).

3 The term 'capital account' refers here to shareholders' equity which consists both of the legal capital amount (effectively the amount paid for the shares) together with any undistributed profits and less any prior losses.

4 The term legal capital is not a term used by the cases addressing distributions or in any of the Companies Acts. It is used here, as elsewhere, to refer to the amount that is the subject of distribution regulation.

5 There is some uncertainty as what the courts meant by reference to capital. The better position it is submitted is that is was nominal issued share capital not paid-up share capital - see Cotton LJ and Lopes LJ's judgments in Lee v Neuchatel (1889) LR 41 Ch.D.1.

6 (1889) LR 41 Ch.D.1

7 Lee v Neuchatel (1889) LR 41 Ch.D.1

8 Ammonia Soda Co. v Chamberlain [1918] 1 Ch. 286.
} 
The European Union's Second Directive reinstated the pre-1889 focus on ensuring that a distribution is not made to shareholders that would result in a reduction of the capital account entry. The preamble to the Second Directive provides 'that provisions should be adopted for maintaining the capital, which constitutes the creditor's security, in particular by preventing any distribution thereof by distribution to shareholders where the latter are not entitled to it'. 9 Post-Second Directive UK scholarship typically refers to distribution regulation as part of the capital maintenance doctrine. However, neither the Directive's provisions or the UK rules implementing the Directive contain any specific requirement to 'maintain capital'. Rather, the rules set forth two accounting-based tests to determine whether a distribution can be made. In the UK the first of these rules, applicable to private and public companies, requires that a distribution can only be made to the extent that a company's accumulated realized profits less previous distributions exceeds its accumulated losses less amounts written off in any formal capital reduction (the 'accumulated profits test'). ${ }^{10}$ The second test, applicable only to public companies, requires that a distribution can only be made to the extent that net-assets exceed the aggregate nominal value of the issued shares and the company's undistributable reserves, which includes any share premium (the 'net assets test'). ${ }^{11}$ Structurally at least, ${ }^{12}$ the net-assets tests results in a reaffirmation of the pre- 1889 UK distribution regulation: legal capital ${ }^{13}$ becomes an explicit factor in the determination of the dividend. The net-profits test has the same effect due, most importantly, to the accumulation requirement and the accounting standards' requirement to depreciate fixed assets. ${ }^{14}$

Recent scholarship has sought 'to elucidate the function of these rules': what they do in fact and who, if anyone, they benefit. ${ }^{15}$ For Professor Armour, in accord with the Second Directive's preamble, distribution rules are viewed as restrictions 'on the return of capital to shareholders'; 16 the net-profits test 'embodies' 17 the capital maintenance rule. Extending the functional inquiry, for Armour the inability to return capital to the shareholders reduces the scope for

\footnotetext{
9 Second Council Directive 77/91/EEC (OJ 1977 L 26/1).

${ }^{10}$ Section 830 CA 2006.

11 Section 831 CA 2006.

12 The capital threshold under the post 1980 regime is, in effect, the amount agreed to be paid for the shares, whereas the pre-1889 threshold was aggregate nominal value, ie, share capital.

13 In contrast to the pre-1889 meaning of legal capital, legal capital post-second directive becomes in effect what is agreed to be paid for the shares including aggregate issued nominal share capital and the share premium account.

14 Financial Reporting Standard 15, Tangible Fixed Assets (ASB, 1999), at [77-102].

15 J. Armour, 'Share Capital and Creditor Protection: Efficient Rules for a Modern Economy' (2000) 63 MLR 355 ('Armour Share Capital'), 355. J. Armour, 'Legal Capital: An Outdated Concept?' (2006) 7 European Business Organization Law Review 5 ('Armour Legal Capital'); Interdisciplinary Group of Capital Maintenance, 'Reforming Capital' (2004) European Business Law Review 919 ('Interdisciplinary Group Report); E. Ferran, 'Creditors' Interests and "Core” Company Law' (1999) Company Lanyer 314. See also, P.O. Muelbert and M. Birke, 'Legal Capital: Is there a Case Against the European Legal Capital Rules?' (2002) 3 European Business Organization Law Review 695; W. Schoen, 'The Future of Legal Capital' (2004) European Business Organization Law Review 429.

16 Armour Legal Capital, ibid 11 and 12.

17 ibid 8-9.
} 
post-contractual opportunism by the company to transfer value from creditors to shareholders. ${ }^{18}$ According to this understanding, at the time of contracting creditors incorporate into their assessment of the risk and required return of their investment the legal capital of the company. If, following the consummation of the contract, the company is able to return legal capital, or an amount representing legal capital in the accounts, to the shareholders then the terms of the agreement are unilaterally altered by the company to the detriment of the creditor. From this perspective, the distribution rules should be understood as providing collective terms for preventing such opportunism.

However, if distribution regulation's function is to prevent legal capital being returned to shareholders, the extent to which it protects creditors in practice is necessarily dependent on the level of a particular company's legal capital. If a company is not required to have and maintain more than an insignificant amount of legal capital then there may be very little for the distribution rules to prevent being transferred. Under English company law there is no minimum capital requirement for private companies and whereas there is a minimum allotted share capital amount for public companies of $£, 50,000^{19}$ there is no requirement for public or private companies to maintain a minimum funded equity cushion. ${ }^{20}$ Distribution regulation may, therefore, protect an insignificant equity contribution from being returned to shareholders. This means that distribution rules do not protect absolutely they only protect relatively: relative to a particular company's capitalization. From this perspective adjusting creditors are the only creditor constituency that can be protected by the rules. If the legal capital threshold below which distributions cannot be made may for some companies be effectively zero, then the distribution rules do not provide a general creditor protection function. Adjusting creditors, on the other hand, can rely on, or attribute value to, the capitalization level in light of the effect of the rules: adjusting creditors can incorporate this information into their decision as to whether or not and on what terms to do business with company. They can rely on both the actual legal capital level and the rules that prevent its distribution. Adjusting creditors are, therefore, distribution regulation's natural constituency. In relation to non-adjusting creditors, Armour concludes that because the maintenance of capital doctrine does not specify the level at which the restrictions on distributions is to be set, it can only protect involuntary creditors when coupled with a minimum capital requirement'. ${ }^{21}$ More recently Armour notes that 'for non-adjusting creditors a restriction on the return of capital to shareholders is by itself of little assistance. This is because if creditors do not adjust, the optimal level of capitalization for

\footnotetext{
18 ibid 12-13.

19 ss.761, 763 CA 2006.

20 If the net-assets of the company fall below half of its share capital. The company must call an extraordinary general meeting to consider the situation. No action is required to be taken (s. $656 \mathrm{CA}$ 2006).

${ }^{21}$ Armour Share Capital, n 15 above, 368 (original emphasis).
} 
shareholders is zero'. ${ }^{22}$ If the level of capitalization is, in fact, set above zero in a particular company then the rules will provide some protection for involuntary creditors. However, as such protection is fortuitous such creditors are not deemed a regulatory constituency. An interdisciplinary group of lawyers and accountants (the 'Interdisciplinary Group'), who recently argued strongly in favour of reforming the distribution rules, also view reliance by adjusting creditors as an important way of making sense of the distribution rules:

Thus creditors may rely on this amount of assets being present to satisfy their claims, unless it has been reduced by trading. Even if it has been reduced in this way, they may rely on the amount of the original capital fund being replenished before assets may be returned to shareholder (emphasis added). ${ }^{23}$

For the Interdisciplinary Group it follows that involuntary creditors should have limited concern about the reform of capital maintenance regulation as by definition... [neither] involuntary or casual creditors rely on the levels of capital maintained by the companies concerned' (emphasis added). ${ }^{24}$

Through this framework, if in practice adjusting creditors place no or little reliance upon legal capital levels at the time of contracting then, from a creditor protection perspective, the rules are ineffective. The Interdisciplinary Group, for example, supports the conclusion that 'there is very little, on balance, to be said in favour of the present regime' with the observation that 'there is very considerable doubt whether creditors rely on it significantly in practice' (emphasis added). ${ }^{25}$ Indeed, both Armour and the Interdisciplinary Group establish convincingly that distribution regulation in its current mandatory form provides insignificant benefits to adjusting creditors. To the extent that distribution prohibitions linked to legal capital are valued by adjusting creditors they are capable of building them into their contractual arrangements with companies. From the adjusting creditors' perspective, to the extent these rules exist at all they should be default rules which may, in some circumstances, allow parties to economise on contracting costs. ${ }^{26}$

When viewed through the lens of the Second Directive's objective to 'maintain' capital, the constituency and reform logic of the above argument is compelling. The problem with the argument, however, is that its logic is connected not to the actual effects of the regulation itself but the stated purpose or function of the regulation: to maintain capital. What the distribution rules can do and who they can protect has come to be understood through the restrictive lens of company law's conceptual order of things: as part of the capital maintenance doctrine. In application, however, rules are inevitably over-inclusive. Even

22 Armour Legal Capital, n 15 above, 12.

${ }_{23}^{23}$ Interdisciplinary Group Report, n 15 above, 928.

24 ibid 932.

25 ibid 947.

${ }^{26}$ On the problems with the argument that a collective term economises on contracting costs see Armour Legal Capital, n 15 above, 22. 
assuming that the distribution rules were designed to protect creditors by maintaining capital vis-à-vis shareholders, in practice the rules' over-inclusive application has generated effects and protected constituencies beyond the boundaries of the original purposive intent. This is not, of course, to dispute the fact that the existing rules, in conjunction with applicable accounting standards, do maintain (vis a vis shareholders) the legal capital accounts of UK companies and that the potential insignificance of the capital contribution for UK companies means that adjusting creditors are the only creditors who can adjust to this firm specific variable. The argument here is that protection of legal capital vis a vis shareholders is but one aspect of what the distribution rules do in practice and only one of the ways in which the rules can benefit creditors. If there is a capital maintenance doctrine then distribution regulation would relate to it diagrammatically as follows:

\section{Figure 1}

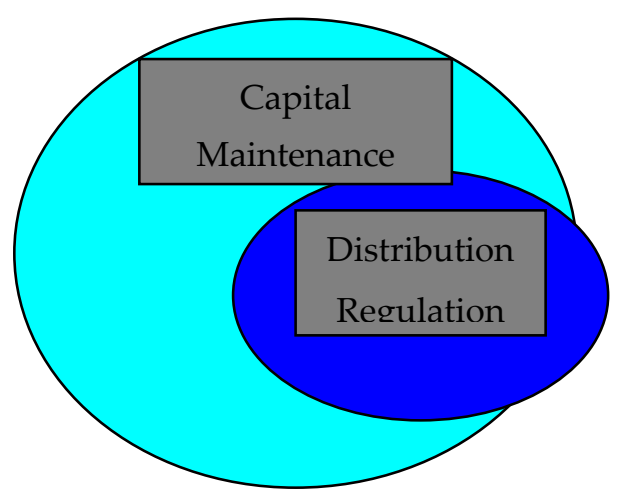

The UK's current distribution rules allow distributions to shareholders to the extent that both net-assets exceed share capital and undistributable reserves ${ }^{27}$ and accumulated realised profits exceed accumulated realised losses. ${ }^{28}$ Both tests do indeed function to ensure that legal capital is not distributable to shareholders. That is not, however, all that they do. By looking at these rules without the lens of the capital return function, we can ask simple but probing questions about the effects of the rules. The net-assets distribution test, for example, involves several components. Broadly understood it prevents distributions until asset value has been generated in excess of all existing liabilities in addition to legal capital. From this perspective, we must also ask how do applicable accounting standards on the recognition of liabilities protect adjusting and non-adjusting creditors when incorporated into the distribution tests? For the accumulated net-profits test the relevant question is how do applicable accounting standards on the recognition of realised profits and losses protect adjusting and non-adjusting creditors when incorporated into the distribution test? The next section sets forth one example

27 S.831 CA 2006, which applies only to public companies.

28 S.830 CA 2006. 
of how non-adjusting creditors may benefit from distribution rules that rely on accounting-based tests.

\section{Protection For Involuntary Creditors Through Distribution REgULATION}

There are two ways in which the regulation of the use and disposition of a company's assets could protect the interests of non-adjusting involuntary creditors. The first type of protection relates to those individuals who have become involuntary creditors. Here regulation can increase the likelihood that involuntary creditors will be remunerated in full and incentivise the company to compensate the claimant quickly. The second type of protection would involve disincentivising investment decisions that produce involuntary creditors or incentivising the taking of appropriate safety precautions to prevent injury to third parties. The constituency of involuntary creditors is protected by reducing the probability that one of us will become an involuntary creditor. Existing UK distribution regulation provides protections for involuntary creditors in both of these respects.

\section{Protecting Existing Creditors}

If any amounts actually or potentially owed by the company to involuntary creditors either decreases net-assets or increases accumulated realised losses, the extent to which the company may make a distribution will be reduced by the amount of the relevant involuntary creditor liability or loss entry. Whether this affects the ability of the company to make the distribution it wishes to make will depend on the size of the liability or loss entry and the value of existing assets and accumulated realized profits.

Pursuant to UK generally accepted accounting principles (UK GAAP), a company's financial statements, in both the balance sheet and through the profit and loss account, must take account of potential as well as actual liabilities. Currently the probability that a liability will have to be paid in the future determines how it is accounted for in the financial statements. Under current UK Financial Reporting Standards, as well as the applicable International Accounting Standards and International Financial Reporting Standards, ${ }^{29}$ the treatment of a potential liability depends on whether it is dealt with as a provision or as a contingent liability, where a liability that must be provisioned being more probable than a contingent liability. If a liability is treated as a provision then the liability is reported on the balance sheet and flows through the profit and loss account. If the liability is deemed a contingent liability it is not recorded on the balance sheet or in the profit and loss account, however, a note to the financial statements will disclose

${ }^{29}$ The standards issued by the International Accounting Standards Board (IASB) are International Financial Reporting Standards. The IASB has also adopted the standards issued by its predecessor the Board of International Accounting Standards Committee which are known as International Accounting Standards (IAS). 
information about such potential liability. The distribution rules note generally that provisions are to be taken account of in determining the amount of any distribution $^{30}$ and specifically that provisions are treated as liabilities for the purpose of the net-assets test ${ }^{31}$ and realised losses for the accumulated profits test. 32

The UK accounting standard on provisions and contingent liabilities is set forth in Financial Reporting Standard 12, Provisions, Contingent Liabilities and Contingent Assets. FRS 12 mirrors International Accounting Standard 37, Provisions, Contingent Liabilities and Contingent Assets which is applicable to the consolidated accounts of UK listed companies. According to FRS 12, a provision, which is defined as 'a liability that is of uncertain timing and amount', 33 must be recognised ${ }^{34}$ when: a company has a 'present obligation' arising from a 'past event'; it is more likely than not that 'economic benefits' must be transferred by the company to settle the obligation; 35 and where a 'reliable estimate' of the amount of the obligation can be made.

A present obligation includes both legal and constructive obligations. Legal obligations include those arising from contract, legislation or operation of law. ${ }^{36}$ Constructive obligations may arise, amongst others, from a pattern of past practice or the creation of an expectation in third parties. ${ }^{37}$ An involuntary creditor such as a person injured by company products or activities, with a product liability or tort claim, would be owed a legal obligation for the purposes of FRS 12. Clearly, in many instances, whether or not a company is liable for such person's injuries may be the subject of dispute. Any legal claim made by such person may well be subject to a vigorous defence by the company. In such contentious circumstances could one say that a 'present obligation' is owed? FRS 12 addresses this issue directly ${ }^{38}$ by using the example of a law suit. ${ }^{39}$ In such circumstances a present obligation is owed where 'taking account of all available evidence, it is more likely than not that a present obligation exists at the balance sheet date' (emphasis added). ${ }^{40}$ FRS 12 notes that 'available evidence' would include expert opinion regarding the likely outcome of the litigation. Accordingly, even where the company's litigation and public posture adamantly denies any responsibility to an involuntary creditor, as

\footnotetext{
${ }^{30}$ S.836(1)(b) CA 2006.

31 S.831(3) CA 2006.

32 S.841(2) CA 2006.

33 Financial Reporting Standard, Provisions, Contingent Liabilities and Contingent Assets (Accounting Standards Board, 1998), 3, at [2]. CA 1985, Sch. 4 at [89] defines a provision as a liability that is likely to be incurred or certain to be incurred but uncertain as to amount. Regulations in this regard will be issued pursuant to section 396 CA 2006.

${ }^{34}$ Financial Reporting Standard, ibid 4.

35 The probability standard in relation to the transfer of economic benefits test is defined as 'the probability that the event will occur is greater that the probability that it will not' (ibid at [23]).

${ }^{36}$ Financial Reporting Standard, Provisions, Contingent Liabilities and Contingent Assets, at [2].

37 ibid at [2].

38 ibid at [15] and [16].

39 ibid at [16].

40 ibid at [15].
} 
far as the company's financial statements are concerned accounting standards force the company to take a more impartial view of its potential liability exposure.

The above example postulates a specific involuntary creditor who makes a claim against the company which the company refutes. However, a present obligation may arise from the company's past activities even where a specific person has not made a claim or has not even been identified at the time the financial statements are issued. In this regard FRS 12 notes that 'it is not necessary, however, to know the identity of the party to whom the obligation is owed - indeed the obligation may be to the public at large'. ${ }^{41}$ Accordingly, providing all other conditions are satisfied, FRS 12 may force a company to take account of potential liabilities to involuntary creditors, even when those creditors themselves are not aware, at the time the financial statements are issued, that they have been injured or who is responsible for the injury. GlaxoSmithKline, for example, provisions for 'unasserted claims' in relation to products that have a 'history of claims'. They calculate the required provision according to the incurred but not reported actuarial technique. 42

The amount of the potential liability that must be recorded as a provision must be the best estimate that can be made, which FRS 12 defines as the 'amount that an entity would rationally pay to settle the obligation at the balance sheet date or to transfer it to a third party at that time'. ${ }^{43}$ Accordingly, if the probability of a legal obligation and the probability of payment to settle that obligation are both greater than $50 \%$ then the net-assets of the company will be reduced by an amount equal to the best estimate of such payment. Such an amount will also be recorded as an expense in the company's profit and loss account, reducing any profit or increasing the loss in the current financial year. It is a realised loss for the purpose of calculating the distribution. ${ }^{44}$ This is the case even in relation to those creditors who are yet to realise that they have been injured or yet to realise who is responsible.

Currently, whilst the claims of involuntary creditors who have a 'more probable than not' claim are taken directly into account by the financial statements, those potential involuntary creditor claims that fall below either of the $50 \%$ thresholds receive only indirect acknowledgement through a disclosure note in the financial statements. These potential liabilities to these creditors do not reduce net assets or increase realized losses. However, recent reform proposals set forth in IASB Exposure Draft IAS 37, Provisions, Contingent Liabilities and Contingent Assets and the ASB's Financial Reporting Exposure Draft (FRED) 39 Provisions, Contingent Liabilities and Contingent Assets propose that even where the probability that economic benefits will have to be transferred to settle the liability is less than $50 \%$, the liability should be recorded in the financial statements rather than, as is

\footnotetext{
41 ibid at [20].

42 Note 23 to GlaxoSmithKline 2004 Annual Report's financial statements.

${ }^{43}$ FRS 12, at [37].

${ }^{44}$ S.841(2) CA 2006.
} 
currently the case, being disclosed in the notes to the financial statements. ${ }^{45}$ The IASB and ASB exposure drafts propose that the lower probability of payment will be incorporated in the amount of the recorded liability. ${ }^{46}$ If such an approach is adopted by the IASB and the ASB both higher and lower probability creditors will receive recognition by the financial statements, increasing the scope for existing and potential involuntary creditor claims to decrease net-assets and distributable profits.

UK and IASB Accounting standards, therefore, require companies to account for claimants that have not successfully obtained an award of damages or even for persons who are not yet aware that they are claimants. By linking distribution rules to accounting standards the distribution rules are required to take account of involuntary creditors' interests. In instances where the size of the provision is considerable, or the existing net-asset and accumulated realised profits position is weak, the involuntary creditor debt will prevent the distribution of funds out of the company.

The important question, however, is whether this link actually protects involuntary creditors' interests by increasing the probability, or to the extent to which, they will be compensated. It is submitted that it does so in two distinct ways. First, where provisioning for the involuntary creditor liability results in a retention of funds, at least in the short to medium term, this reduces the probability of insolvency. Whilst it is true that the company may not be able to identify and exploit profitable opportunities with these funds, and that any investment could be wasted, until the point in time where the invested funds generate losses in excess of the value of the investment, the company's assets available to settle the involuntary debt exceed what would have been available had the distribution taken place. Second, shareholders have incentives after the incurrence of debt, including involuntary debt, to alter the risk profile of their investments by making riskier investments thereby decreasing the value of existing debt and increasing the value of the equity investment. ${ }^{47}$ Whilst managers may not share the same incentives as shareholders in this regard, as Armour points out, the extent to which executive compensation arrangements improve the alignment of managerial and shareholder interests, the incentives for managers to expropriate

\footnotetext{
45 Exposure draft of proposed amendments to IAS 37, Provisions, Contingent Liabilities and Contingent Assets, at [22-26].

46 ibid at [23].

47 Armour Share Capital, n 15 above, 360. Consider, for example, a company which has assets of $£, 500$ consisting of $£, 250$ of equity investment and a loan of $£ 250$ at a $10 \%$ interest rate. If it invests $f, 500$ in US treasury stock at a $10 \%$ annual return, at the end of one year there is $100 \%$ chance of a payment of $f 550$. The expected value of both the equity and the debt would be $£ 275$. If, however, the company following receipt of the loan invests the funds in a risky project which has a $50 \%$ chance of a payment of $£ 2000$ and a $50 \%$ of 0 , the value of the debt decreases to $£ 162.50(50 \%$ of $£ 275$ plus $50 \%$ of 0$)$. However, the value of the equity increases to $£ 725$ (50\% of $£^{2} 2000$ plus $50 \%$ of 0 minus $£ 275$ ). A similar example is set forth in J.H. Choper, J.C. Coffee, and R.J. Gilson, Cases and Materials on Corporations (New York: Aspen, 2004) 220.
} 
value from debtholders also increases. ${ }^{48}$ These incentives to expropriate value increase as the funds the shareholders have invested in a company decrease, as they have less to lose and more to gain from riskier investments. Choper, Coffee and Gilson, drawing on the seminal work of Black and Scholes, ${ }^{49}$ describe this incentive structure in terms of option pricing theory, where shareholders are viewed as holders of an option to purchase the company from the debt holders when the option is in the money (the value of the company exceeds the value of the debt). They note that 'option pricing theory provides that increasing the variability of the [value of the] underlying asset increases the value of the option'. ${ }^{50}$ As the value of an option is never less than zero, a valuation of the option will ignore the negative value of probability outcomes that would value the underlying asset (in our case the value of the company) at less than the exercise price of the option. ${ }^{51}$ Therefore, although increased variability in company value may increase the range of negative as well as positive outcomes, the valuation of the shares can ignore the extent to which the negative outcomes fall below the exercise price (value of the company is less than the value of the debt). As risk is a function of the variance in an asset's expected return ${ }^{52}$ the option holder, in this case the shareholder, is incentivized to increase the risk profile of the asset, namely, the company's investments. Choper et al note, however, that the option pricing analogy is qualified as shareholders actually have wealth tied up in the company that could be lost if the return on the investment is negative. It follows, therefore, that 'shareholders' incentives to act like option holders increases as the value of their [shares] decreases'. ${ }^{53}$ The value of their shares necessarily decreases by the amount of any received distribution. Accordingly, the extent to which provisioning for involuntary creditor debt prevents a distribution or part thereof, it reduces the shareholders' incentives to expropriate value from existing involuntary creditors.

The effect of linking distribution rules to the company's financial statements only provides relative protection for involuntary creditors. However, this relative protection makes good sense. It does not prevent distributions per se, it only does so when the company enters the margins of accounting bad health. Some scholars rightly note that it is problematic to rely on accounting-based tests to determine the legitimacy of distributions as there may be considerable disparity between a company's real and accounting well being. ${ }^{54}$ To deny involuntary creditors

48 ibid 360. The extent to which manager and shareholder interests are aligned appears to have improved markedly over the past decade. See M. J. Conyon and G. V. Sadler, 'How Does US and UK CEO Pay Measure Up?' (2005) working paper on file with the author.

${ }^{49}$ F. Black and M. Scholes, 'The Pricing of Options and Corporate Liabilities' (1973) 81 Journal of Political Economy 637.

${ }^{50} \mathrm{n} 47$ above, 220. See generally R.A. Brealey, Principles of Corporate Finance (London: McGraw-Hill, 1991) 633-635.

${ }^{51}$ For example, a $10 \%$ chance of the shares being worth $£ 20$ when the exercise price is $£ 60$ is, in the expected value calculation, $10 \%$ of zero not $10 \%$ of $(-40)$.

52 See footnote 59 on expected value.

53 n 47 above, 221.

${ }^{54}$ Interdisciplinary Report, n 15 above, 938. 
protection on these grounds would, however, be to deny them what sophisticated voluntary creditors choose to rely on. Financial covenants in the UK, for example, are often linked to accounting based targets. ${ }^{55}$ Although direct distribution restrictions are more common in the United States than in the UK, ${ }^{56}$ indirect distribution restrictions such as broadly defined accounting-based net-worth provisions ${ }^{57}$ are often included in UK debt contracts and have largely the same effect. 58

\section{Protecting the Constituency}

As is well known, and set forth in terms of option pricing theory above, one effect of limited liability is that when a rational company assesses the expected value ${ }^{59}$ and the required return from an investment no account need be taken of possible losses in excess of the value of the company. To use Professor Leebron's example of a biotechnology investment, 'if shareholders enjoy limited liability, there is no chance that the shares are worth less than zero - even though, for example, there may a $0.1 \%$ chance that a dangerous organism will escape causing extensive injury and legally triggering mammoth corporate liability'. ${ }^{60}$

Such negative returns are externalized onto third parties unless such third parties take account of such costs in the terms on which they do business with the company. Adjusting creditors could, for example, increase their required return from the business relationship with the company to reflect the actual rather than the distorted risk and expected return of the company's investments. Involuntary creditors by definition, however, are not ex-ante in a position to force the company and its shareholders to internalise the costs that are, or could be, imposed on them by the company's investments. If such externalities are realized the involuntary creditor bears these costs. This leads Hansmann and Kraakman to conclude that limited liability incentivizes shareholders 'to spend too little on precautions to avoid accidents' and 'encourages overinvestment in hazardous industries'. ${ }^{61}$ Limited liability, therefore, increases the likelihood that company investment decisions will produce involuntary creditors and it increases the

55 D. Cirtron, 'The Incidence of Accounting Based Covenants in UK Public Debt Contracts: An Empirical Analysis' (1995) 25 Accounting and Business Research 139 noting that 30\% of analyzed public debt contracts contained accounting based covenants.

56 C. Leuz, D. Deller and M. Stubenrath, 'An International Comparison of Accounting Based Payout Restrictions in the United States, United Kingdom and Germany' (1998) 28 Accounting and Business Research $111,115$.

${ }^{57}$ Leuz, et al note that the accounting definition of net worth is 'the aggregate of paid-up share capital, specific reserves (eg., share premium, capital redemption) as well as the accumulated profit and loss account' (ibid 120)

58 ibid 120 .

59 Leebron defines expected value as follows: 'the expected future value of each outcome is the probability of each outcome multiplied by its value; the expected future value of the investment is the sum of all such expected values for each possible outcome' (D.W. Leebron, 'Limited Liability, Tort Victims and Creditors' (1991) 91 Columbia Law Review 1565, 1570).

60 ibid 1571 .

${ }^{61}$ H. Hansmann, and R. Kraakman, 'Toward Unlimited Shareholder Liability for Corporate Torts' (1991) Yale Law Journal 1879, 1882-83. 
likelihood that business activities that have a high probability of producing involuntary creditors will take place through thinly capitalised limited liability companies.

Hansmann and Kraakman note further that these "perverse incentives...are exacerbated...if [the shareholder] can withdraw her capital from the firm prior to the time when tort liability attaches'. ${ }^{62}$ If a shareholder can withdraw funds prior to the time liability attaches then, in making or directing the investment decision, the risk of losing any or all of the investment are diminished and the incentive to ignore possible costs externalized on involuntary creditors is thereby increased. The current UK distribution rules, however, dampen these perverse incentives. By linking the distribution test to accounting rules that take account of involuntary creditor liabilities a considerable time before liability attaches, the window of opportunity for shareholders to receive a return on their investment through a distribution is considerably attenuated and the incentives to make perverse investment decisions thereby reduced. ${ }^{63}$ Accordingly, current distribution rules contribute to reducing the constituency of involuntary creditors by weakening the incentive to take investment decisions which do not take full account of the costs that may be imposed on non-consenting third parties.

The extent to which distribution regulation can weaken these incentives is a function of whether non-distribution mechanisms can be deployed to transfer company assets to the shareholders. Such mechanisms would include, for example, interest and principal payments, management fees or transfer pricing whereby the prices paid for goods and services exceed their market value. Outside of ordinary course debt, however, there are limits on the extent to which such transfers can be made effectively without risk of challenge. Corporate law, corporate insolvency law and accounting regulation all operate to place restraints on such transfers. Payments made for products, services or debt that greatly exceed market value are likely to be a breach of a director's duty of care ${ }^{64}$ and even the subjective duty to promote the success of the company for the benefit of the members as a whole. ${ }^{65}$ While the company is solvent actions based on breach of duty will be of no concern to directors as the benefiting shareholder controls the company. However, in a thinly capitalised company the probability of insolvent liquidation is high and the possibility of suit by a liquidator-controlled company significant. Accounting regulation requires broad disclosure about related party transactions pursuant to Financial Standard 8: Related Party Disclosures ${ }^{66}$ that would enable the liquidator and affected involuntary creditors to identify suspect transactions. Furthermore, the incentive counterbalance provided by the

\footnotetext{
62 ibid 1884.

63 See C. Leuz, 'The Role of Accrual Accounting in Restricting Dividends to Shareholders' (1998) 7 European Accounting Review 579, 580 making this argument. See W. Schoen, 'The Future of Legal Capital' (2004) 5 European Business Organization law Review 429, 447 suggesting a similar argument.

${ }^{64}$ Section 174 CA 2006.

65 Section 172 CA 2006.

${ }^{66}$ Financial Reporting Standard: Related Party Disclosures (ASB, October 1995).
} 
current distribution rules receive support from section 423 of the Insolvency Act 1986 that allows a involuntary creditor, as the victim of the undervalue transaction, ${ }^{67}$ to petition the court to restore the company's position to what it would have been had the undervalue transaction not taken place. ${ }^{68}$ The petitioner must demonstrate that the transaction was intended to put assets beyond the reach of the involuntary creditor. ${ }^{69}$ This provision is, arguably, particular useful in relation to such mechanisms such as excessive interest and other types of transfer pricing and management fees where the market value of the product or service is available using industry comparisons. To the extent that such payments can be presented as exorbitant they may be subject to ex-post challenge. Accordingly, whilst these transfer mechanisms do undermine the incentive counterbalance provided by the UK's distribution rules, as there are limits on the effectiveness of such mechanisms the incentive counterbalance of UK distribution regulation continues to have traction. Existing distribution regulation, therefore, operates as a disincentive to corporate actions that produce involuntary creditors.

\section{Assessing Significance}

This article submits that the UK's current distribution rules provide regulatory benefits for involuntary creditors. However, the question remains whether these benefits are significant enough to be taken into account in the debate about the effectiveness and possible reform of the distribution rules. We have seen that in relation to existing involuntary creditors the protection is triggered only as the company approaches the margins of accounting good health and, when triggered, offers only a variable increase in the probability of being paid and a variable decrease in the probability that the existing value of the debt will be opportunistically expropriated. In relation to small claims against large companies the benefit is surely insignificant. As the size of the claim as a proportion of a company's net-worth or accumulated profitability increases, the variable protection provided by the rules will also increase. In relation to the constituency of involuntary creditors we have seen that the extent to which current distribution rules counter-balance the incentives not to take full account of the potential costs an investment imposes on involuntary creditors varies as a function of the net-asset value of the company making the investment decision and the availability and effectiveness of non-distribution mechanisms for transferring assets to shareholders.

In assessing the contemporary significance for involuntary creditors of these distribution rule-effects account must be taken of alternative stand alone protections that are in place and also those that law reform could put in place. For example, product liability insurance is taken out by most companies although there

\footnotetext{
${ }^{67}$ Section 424(1)(c) Insolvency Act 1986. Where the company is being wound-up an involuntary creditor action would require leave of the court (s.424(1)(a). The liquidator of the company could also bring such an action (s.424(1)(b)).

68 S.423(2)(a) Insolvency Act 1986.

${ }^{69}$ S. 423(3)(a) Insolvency Act 1986.
} 
is no mandatory requirement to do so or to obtain a specified amount of coverage. Indeed in most instances insurance cover will satisfy the claim in full. ${ }^{70}$ Only in instances where external cover is not taken or is inadequate or unavailable ${ }^{71}$ will these regulatory benefits make a difference.

From a reform perspective, more effective protections of involuntary creditors' interests than those provided by distribution regulation can readily be envisaged. ${ }^{72}$ Mandatory product liability insurance with minimum coverage ratios depending on company turnover, or market capitalization, or risk-based industry type would be one approach. ${ }^{73}$ A no-fault state funded compensation system, such as provided in New Zealand, ${ }^{74}$ would be a more comprehensive and radical option. Alternatively, involuntary creditors could be given priority over voluntary creditors in bankruptcy which would increase the extent to which existing involuntary creditors are compensated by insolvent companies and provide voluntary creditors with strong incentives to ensure that corporate actions did not produce involuntary creditors. It seems clear that such reform options would so outweigh the identified benefits of distribution regulation as to render them insignificant. Importantly, however, there is no indication whatsoever that such reforms in the UK are being considered or that they are politically viable. ${ }^{75}$ Theoretical but unrealistic protections do not trump erratic and variable but existing benefits.

In relation to the distribution rule-effects which counterbalance limited liabilities' incentive to ignore costs imposed on involuntary creditors, we have seen that non-distribution mechanisms will enable well-advised parties to take some of the generated cash out of the company prior to injury, the victim's awareness of injury, or claim. Furthermore, even where the distribution rules coupled with the law of directors' duties, accounting disclosure standards, and the regulation of undervalue transactions create foreseeable difficulties in this regard, the parties may still choose to make the investment. After all, at the time of the investment the involuntary creditor and the company's insolvent liquidation leading to breach of duty claims and challenge to undervalue transactions are all mere probabilities. On the other hand, as a counterbalance to these skewed incentives distribution

\footnotetext{
70 Brian Cheffins, Company Law: theory, structure and operatoin (Oxford: Clarendon Press, 1997) 507.

71 Easterbrook and Fischel, The Economic Structure of Corporate Law (London: Harvard University Press, 1991) 61 suggesting that insurance may not always be available for smaller companies.

72 Professor Enriques and Macey argue, for example, that 'society can find more efficient and less costly ways to protect involuntary creditors--such as piercing the veil of misbehaving close corporations' (L. Enriques and J. Macey, 'Creditors verus Capital Formation: The Case Against The European Legal Capital Rules’ (2001) 86 Cornell Law Review 1165, 1185).

73 Involuntary creditors in the UK are provided with a degree of protection by the Third Party (Rights Against Insurers) Act 1930 which ensures that the insurance claim of an insolvent insured is transferred to the creditor to prevent other creditors having any claim to the insurance proceeds.

74 See I. Campbell, Compensation for Personal Injury in New Zealand: Its Rise and Fall (Auckland: Auckland University Press, 1996). On whether this system is truly a no-fault system see C. Flood, 'New Zealand's No-Fault Accident Compensation Scheme: Paradise or Panacea' (2000) 8 University of Alberta Health Law Review 3.

75 Ferran above n. 15, 323 notes that 'the historical evidence of insolvency law reform in the United Kingdom suggests that proposals along these lines are unlikely to receive a favourable welcome'.
} 
rule-effects occupy an empty room. English law is wedded to a commitment to separate legal personality that provides no scope for piercing the veil to hold shareholders, even a $100 \%$ shareholder, liable to involuntary creditors because they are involuntary creditors. ${ }^{76}$ No mandatory regulatory mechanism, such as mandatory insurance or a priority in bankruptcy rule counteracts these skewed incentives. ${ }^{77}$ Involuntary creditors as a constituency continue to get a poor deal from the regulatory settlement that enables business to be conducted through the corporate form. ${ }^{78}$

Furthermore, this assessment of significance for involuntary creditors must be placed in the context of the significance of the distribution rules for adjusting creditors. How effective are these provisions in actually protecting adjusting creditors from credit default? The nature of the regulatory benefits themselves are identical to those identified above in relation to existing involuntary creditors: by limiting the ability of companies to distribute funds to shareholders they provide qualified reduced bankruptcy risk ${ }^{79}$ and reduce the shareholders / managers incentives to expropriate value through excessive risk taking. As noted above, the extent of the benefit, and the price that adjusting creditors would be willing to pay for this benefit, varies according the company's capitalization. In contrast, the benefit for involuntary creditors varies as a function of the size of the claim relative to company's accumulated net-profit or net-asset status. That is, for adjusting as well as for involuntary creditors the extent to which distribution regulation provides protection is a function of an external variable rendering those benefits erratic and uneven in application. As noted above, several scholars recognise that these adjusting creditor benefits are indeed variable in application and, accordingly, argue that the rules should either be default rules or left to private ordering to incorporate them into debt agreements. ${ }^{80}$ This makes sense where creditors can adjust to make use of, and pay for, the rules only where they make a difference. But for involuntary creditors to abolish them is to remove any scope for their beneficial application. To make the rules default-rules is to render their beneficial application dependant on the unconnected good fortune of adjusting creditor election.

\footnotetext{
76 Adams v Cape Industries [1991] 1 All ER 979.

77 It would counteract these incentives by incentivising insurers or voluntary creditors, respectively, to monitor investment implications for the involuntary constituency. Of course they may, dependent on the corporate activity, be subject to external regulatory check such as product and health and safety regulation. However, the costs of regulatory sanctions imposed on the company do not alter the fact that externalities below the value of the company can be ignored.

${ }^{78}$ Hertig and Kanda note that 'to date... almost no specialized measures to protect involuntary creditors have been adopted anywhere'. They offer the following explanation for 'this lacuna': 'since tort victims do not know they will become victims, they have little incentive to lobby for corporate law reform before they are injured. After injury, however, it may be too late to lobby for reform because their damages are fixed, and they can no longer benefit from a change in the law' (G.Hertig and H. Kanda, 'Creditor Protection' in Kraakman et al (eds), The Anatomy of Corporate Law: A Comparative and Functional Approach (Oxford: Oxford University Press, 2004).

79 Armour Share Capital, n 15 above, 367.

80 ibid 378.
} 


\section{THE DISTORTION DRIVER}

\section{DiSTORTION AND THE SOLVENCY SOLUTION}

If distribution regulation protects only those creditors who can adjust to a company's actual legal capital and if, in practice, those adjusting creditors do not value distribution protection organized around the legal capital threshold then the case for reform is straightforward. If, however, as is submitted by Part II of this article, a case is made that the distribution rules provide variable but at times significant benefits for involuntary creditors then an alternative case for reform must be made. Although not accepting that distribution rules offer significant benefits for involuntary creditors, the Interdisciplinary Group's analysis of distribution regulation offers such an alternative case. ${ }^{81}$

Accounting regulators in promulgating accounting standards are concerned to ensure that accounting information produced by companies is, amongst others, reliable as well as relevant and useful for both shareholders in holding management to account and investors when considering whether to invest in or lend money to the company. ${ }^{82}$ Accounting regulators may not have regard to the implications of those standards for the ability of companies to make distributions, yet, as we have seen, current distribution regulation is directly dependent upon those accounting standards. This can result in changes to accounting standards that generate more relevant, reliable and useful financial statements but which distort the application of distribution regulation. In the worst case this can inhibit solvent and successful companies from making distributions where such distributions would not threaten creditor interests. The distribution constraints placed upon such companies may increase their cost of capital because this results in them losing the community of investors who, for tax, liquidity or other reasons, require regular dividends.

The primary reason for this distortion is that the standard accounting practice of accrual accounting accounts for transactions not cash flows. Entries are made in the balance sheet and the profit and loss account at the time an obligation is incurred or an amount agreed to be paid; this may differ significantly from the timing of cash outflows to satisfy those obligations or cash inflows to pay for products delivered or services rendered. Accordingly, companies may be required to recognise a liability or a loss entry that results in a weak financial position from the viewpoint of the financial statements even though at that point in time its cash flows and probable solvency are very healthy. The Interdisciplinary Group's primary example in this regard is the consequences of accounting for defined pension deficits under Financial Reporting Standard 17: Retirement Benefits. Under this

${ }^{81} \mathrm{~J}$. Rickford et al, 'Reforming Capital: Report of the Interdisciplinary Group on Capital Maintenance' (2004) 15 European Business Law Review 919 ('Interdisciplinary Group Report').

82 Accounting Standards Board, Statement of Principles for Financial Reporting (ASB, 1999). 
Standard the company must recognise on its balance sheet defined benefit pension deficits calculated on an actuarial basis. ${ }^{83}$ As has been widely reported, ${ }^{84}$ many companies have recently found their pension funds to be in considerable deficit. The recognition of these liabilities has had a significant detrimental impact on many companies' balance sheets, in worst cases placing them in technical insolvency 85 with assets less than liabilities. These companies, however, may remain cash-strong and successful companies who would have no difficulty in paying debts today and as they arise in the foreseeable future. As creditors are concerned with being paid, regulations that prevents asset distributions to shareholders when this creditor concern is in no way jeopardized appears pernicious and requires justification. 86

According to the Interdisciplinary Group, the distortions generated are not justified by the benefits provided by existing distribution regulation, which they view as largely ineffective as a creditor protection device. ${ }^{87}$ Consistent with Armour's position set forth above, the Interdisciplinary Group views the ability of creditors to rely on and adjust to the existing distribution rules in light of a company's legal capital as crucial to the rules having practical value. 88 The fact, therefore, that the available empirical evidence suggests that they are not in practice 'relied upon by creditors's9 (and certainly not by involuntary creditors ${ }^{90}$ ) renders them of 'insufficient value' 91 to justify the distribution distortions they generate. The Group argues that a creditor's 'core' interest is in a company's solvency - its ability to satisfy the creditors' obligations. ${ }^{92}$ Involuntary creditors' interests are, they note, 'essentially a fair prospect of solvency'. ${ }^{93}$ The solution, therefore, is to disconnect distribution regulation from the financial statements. ${ }^{94}$ The focus of regulation, they submit, should be on ensuring that companies have the flexibility to make distributions when the company's immediate and future solvency is not in question. Accordingly, a company should be permitted to make

83 FRS 17: Retirement Benefits (ASB, 2000), at [37].

84 'Pension deficits almost equal company profits' (21 February 2003) Financial Times.

${ }^{85}$ Interdisciplinary Group Report, n 81 above, 960.

86 It is important to understand, however, that regardless of distribution regulation, FRS 17 may drive dividend reduction in cash flow positive companies where available funds are used to address the deficit. Other pressures encourage companies to clean up these deficits, for example, possible downgrades from credit rating agencies (see LEX 'A Pension Deficit Disorder' (8 February 2003) Financial Times. In many instances current distribution regulation may not, therefore, be a 'but for' cause of the dividend reduction. ${ }^{87}$ Interdisciplinary Group Report, n 81 above, 931-933.

88 ibid 932 noting that 'evidence to the [Company Law Review] was to the effect that little, if any, importance was attached by such creditors to debtors' actual levels of share capital'.

89 ibid 982.

90 ibid 932 noting that 'nor by definition do involuntary or casual creditors rely on the levels of capital maintained by the companies concerned' and footnote 174 noting that 'involuntary creditors...do not rely on capital reserves'.

91 ibid 982.

92 ibid 967.

93 ibid footnote 174.

${ }^{94}$ In reaching this solvency determination the Interdisciplinary Group recognise that regard will be had to the accounts; but whether a distribution can be made would under this approach would no longer be dependent on the application of an accounting formula (ibid 980). 
a distribution provided that directors can certify the solvency of the company for the foreseeable future:

The directors should be required to reach the view that for the reasonably foreseeable future, taking account of the company's expected prospects in the ordinary course of business, it can reasonably be expected to meet its liabilities. ${ }^{95}$

If, however, as is argued in Part II of this article, existing distribution regulation provides certain protections for existing as well as the constituency of potential involuntary creditors, this assessment of the costs and the benefits of the existing rules is altered: do these identified benefits - particularly in light of the limited protection provided to involuntary creditors generally - justify the existing rules in spite of the identified distortions? At a minimum, the ease with which the Interdisciplinary Group moves from distortion to reform is problematised by these involuntary creditor benefits: if distortions are created from creditor protection rules that in practice do not benefit any creditors, then reform is imperative; but if some weak creditors such as involuntary creditors do benefit then we may be more hesitant in our acceptance of the case for reform; more demanding of the case that distortions are generated and that their consequences for UK companies are significant.

There is, however, no obstacle placed in the path of the Interdisciplinary Group's cost-benefit analysis for reform if their solvency certification reform proposal provides equivalent protection for involuntary creditors as is provided currently under the existing regime. If that is the case, the distortions would be removed whilst the level of protection would be unaltered and involuntary creditors would be indifferent to reform.

\section{WOULD A SOLVENCY TEST UNDERMINE CURRENT INVOLUNTARY CREDITOR PROTECTIONS?}

From the perspective of the involuntary creditor constituency, the question is whether the adoption of such a solvency standard would detrimentally affect the protection which, it is argued above, is provided by the UK's current distribution rules. Consider a public pharmaceutical company with significant positive cash flow which is able to meet its debts when due and, subject to the problem set forth below, expects to meet these debts when due for the foreseeable future. This company is, however, aware that certain of its now withdrawn pregnancy healthcare products may cause congenital liver problems for the children whose mothers took the product during their pregnancy. However, those affected are unlikely to experience any symptoms until they reach puberty. These long-tail claims may well destroy the company when they are made in 10 to 15 years time. Current provisioning rules would require that a provision is recorded on this year's

95 ibid 979. 
balance sheet putting the company in technical insolvency and preventing any distribution. They do not, however, affect the company's current or medium term ability to pay its debts. Would a solvency certification approach allow a dividend?

Consider for example, the recently introduced solvency-based test for capital reductions for private companies. Pursuant to section 641 of the Companies Act 2006, a private company may reduce its share capital ${ }^{96}$ by passing a special resolution approving the reduction which is supported by a solvency statement made by all the directors to the effect that the company can pay its debts at the time of the statement and as they fall due over the following year. ${ }^{97}$ It is clear that, in the context of the above hypothetical where the latent liability exposure would not have any affect on the company's cash flow or solvency for 10 to 15 years, a solvency approach for distributions which requires a short-term, fixed time solvency statement would allow a distribution where the current rules would not. The introduction of such a solvency approach for distribution regulation would, therefore, represent a deterioration in the protection provided to involuntary creditors by the current distribution rules. The Interdisciplinary Group, however, propose a broader principles-based time frame that asks the directors to certify solvency in the reasonably foreseeable future. In theory, this would, along with the current distribution rules, restrict the distribution if a reasonable director would foresee no way of avoiding insolvency 10 or 15 years in the future.

The adoption of a principles-based approach to the time period to which the solvency certification applies increases the exposure that directors have to ex-post sanction resulting from a court process brought by a liquidator (as compared to their exposure under a fixed time period certification): will the court, who will assess the legality of the dividend with the knowledge that the company has failed, take a more expansive view of what was reasonably foreseeable at the time of the dividend? Will the court judge reasonableness with the hindsight of failure? This potential exposure could lead directors to take a risk averse position and refuse to give the solvency certification where there are possible and significant long-tail claims. In theory, this could render a solvency test more protective of involuntary creditors than the current rules (that require provisioning where the probability of payment is $50 \%$ or more) if risk averse directors refuse to pay dividends where the possibility of paying a future claim is less than $50 \% .{ }^{98}$

This incentive for directors to be conservative is, however, significantly mitigated in relation to long tail claims by three factors. First, although there may

\footnotetext{
96 Pursuant to section 610(4) Companies Act 2006 for the purposes of the capital reduction procedures the 'share premium' is treated as part of the 'share capital'.

${ }^{97}$ S.643 Companies Act 2006

98 As a solvency based test will take account of contingent liabilities (see, s. 643(2) CA 2006), replacing the current rules with a solvency test will increase the protection for those potential involuntary creditors who have less than a $50 \%$ chance of receiving compensation (ie., they represent contingent liabilities) because the current accounting rules on contingent liabilities mean that such claims do not reduce net assets or increase realised losses. Paradoxically, therefore, a solvency based test will increase protection for those involuntary creditors less likely to be compensated and decrease it for those more likely to be compensated. If the approach in FRED 39 is brought into effect, this paradox will disappear. I would like to thank Eva Micheler for assisting me in seeing this point.
} 
be serious concerns about long term solvency, it may, given the company's product line and research and development activity, be reasonable for a director to conclude that the company would be in a position to negotiate and settle future claims, even if at the time the claims are made in the future this turns out not to be the case. Such a solvency assessment is a business judgement and UK courts have typically treated such judgments deferentially. ${ }^{99}$ Furthermore, a carefully crafted record supporting the assessment of reasonableness of the certification is likely to deter many a liquidator from deploying its limited funds on further litigation.

Second, directors making a distribution decision are faced with the immediate concern that unhappy shareholders may remove them versus a probability of future liability. ${ }^{100}$ Similarly, directors who are shareholders may be swayed with the incentive of immediate funds versus probabilistic future liability. Importantly, in relation to unlawful dividends the present value of a director's future liability is less under a reasonably foreseeable future solvency based test than it is under the current distribution rules. The reason for this is that if the distribution is illegal under the current distribution rules then director liability is effectively strict unless made on the basis of inaccurate accounts which permitted the distribution and in relation to which the directors took reasonable care to secure their accurate preparation. ${ }^{101}$ Under the existing rules, a director who makes an illegal dividend based on accurate accounts discounts his future liability, therefore, only by the probability of insolvency (resulting in the liquidator bringing an action on behalf of the company for breach of duty). A director who makes a dividend under a solvency-based approach which he believes is illegal discounts his future liability not only by the probability of insolvency but also by the probability that a plausible (although in the director's opinion false) argument that the solvency statement was reasonable will have either settlement value 102 or be accepted by the court.

\footnotetext{
${ }^{99}$ Howard Smith v Ampol Petroleum Ltd [1974] AC 821.

${ }^{100}$ In this regard Professor Schön notes that compared to a solvency standard relying on accountingbased rests 'makes it easier for managers to refuse to make distributions to the shareholders in times of crisis' (Schön, n 15 above, 446).

101 Under the current distribution law, the basis of for director liability is a conceptual blend of trust law and the duty of care. Whereas breach of trust is the regularly referred to as the basis of liability the law contains an element of fault that belongs to the law of negligence. In Leeds Estate Building and Investment Co v Sheppard (1887) 36 Ch.D. 787 for example, a directors liability was dependent on the determination of whether he had taken reasonable care. Under a solvency based approach, the courts could continue to determine liability on a breach of trust basis: a dividend issued under an inaccurate solvency statement would be an unlawful dividend which would amount to a breach of trust. However, the solvency approach alters the logic of the liability analysis in a way that would suggest the basis of liability will become the duty of care alone. Under current distribution law a dividend that does not comply with the accumulated net-profits tests and the net-assets test is an unlawful dividend. The determination of whether or not the directors are at fault and, therefore, liable does not alter the fact the dividend is unlawful. That is, there is a breach of trust but liability may be waived for that breach if the director is not at fault. In contrast, under the solvency approach the existence of the directors' fault (ie., the making of solvency statement when there were no reasonable grounds to make that statement) determines whether or not the dividend was unlawful. This may mean that breach of trust fades into the background as the basis of director liability under a solvency standard.

102 Settlement value here means that the liquidator will accept less than the claimed amount without a court process as she is aware that there is some risk that the court will accept the 'reasonableness' argument made by the director resulting in no award.
} 
Third, the actual time frame within which directors have to think about solvency under a reasonably foreseeable future test may be curtailed by the limitation periods applicable to any action that could be brought against the director in relation to an unlawful dividend. Any action based on breach of trust ${ }^{103}$ would be subject to a six year limitation period ${ }^{104}$ unless it can be demonstrated that the directors acted fraudulently. ${ }^{105}$ Actions based upon breach of duty of care are also subject to a six year limitation period. ${ }^{106}$ This period may be extended if it can be demonstrated that the company was not aware of the breach until a date subsequent to the unlawful dividend, ${ }^{107}$ in which case it will be extended to three years from that date. However, given that the board of the directors is the primary agent of the company and would have unanimously ${ }^{108}$ approved of the solvency statement, it is unlikely that the company will benefit from this extension. ${ }^{109}$ In relation to breach of duty, pursuant to section 32(2) of the Limitation Act 1980 the six year period will not run if the directors are found to have deliberately concealed the breach, and they will deemed to have deliberately concealed the breach if they deliberately breach the duty in circumstances that are unlikely to be discovered for such time'. Whilst under the hypothetical case of the pregnancy healthcare drug the breach will certainly not be discovered for some time, the burden of demonstrating a deliberate breach is a very high one, that is unlikely to be fulfilled in a company that can make a plausible, even if unreasonable, long term business case that the involuntary creditor obligations will be met. Arguably, therefore, the law of limitation periods reduces an open ended 'reasonably foreseeable future' solvency test to six years. Accordingly, a solvency test, whether based on either a fixed-time period as in capital reductions under the Companies Act 2006 or based on solvency for the reasonably foreseeable future as proposed by the Interdisciplinary Group, could enable distributions to be made where there exist substantial long-tail claims that the current regime would prohibit. The constituency of involuntary creditors, were they capable of acting collectively, would, therefore, object to these reform proposals.

\footnotetext{
103 See In re Exchange Banking Company (Flitcroft's Case (1882) LR 21 Ch.D. 519) suggesting that an action for unlawful dividend is based on breach of trust.

104 Section 21 (3) Limitation Act 1980. See generally, the Court of Appeals judgment in Gwembe Valley Development Company Limited v Koshy [2003] EWCA Civ 1048.

105 Section 21(1)(a) Limitation Act 1980.

106 Section 2 Limitation Act 1980. See Gwembe Valley Development Company Limited v Koshy [2003] EWCA Civ 1048.

${ }^{107}$ Section 14A(4) Limitation Act 1980.

108 The solvency statement under section 643 CA 2006, for example, requires that 'each of the directors' makes the solvency statement.

109 Considering the attribution of a state of mind to the company Jennifer Payne argues, interpreting Meridian Global Funds Management Asia Ltd v Securities Commission [1995] 2 AC 500, that 'in short where a state of mind needs to be attached to the company that state of mind needs to arise from a board resolution or the unanimous agreement of the shareholders' (J. Payne, 'Unjust Enrichment, Trusts and Recipient Liability for Unlawful Dividends' (2003) 119 Law Quarterly Review 583).
} 


\section{CONCLUSION}

If the function of UK distribution regulation is to maintain the legal capital account as an undistributable reserve, then its natural constituency is the adjusting creditor. Recent commentary operating though this capital maintenance lens has demonstrated that if the function of distribution regulation is to protect adjusting creditors then it is ineffective and unnecessary: to the extent sophisticated creditors rely on such protections they could negotiate for them in the absence of mandatory provision. At best, such provisions should be optional: available for those who wish to opt-in. However, the focus on legal capital circumvents a broader consideration of the beneficial effects of the distribution rules for involuntary creditors. Linking distribution regulation to company financial statements provides tailored and proportionate benefits for involuntary creditors which increase the probability that their claims will be satisfied and decreases the probability that they will become claimants in the first place. Replacing these rules with a solvency based standard will provide a lower level of protection for involuntary creditors, particular long-tail claimants.

None of this means that proposals to abolish existing rules and to replace them with an solvency test are mistaken. It may indeed be the case that the disadvantages of the existing rules could be so burdensome for UK companies that they outweigh the costs reform would impose on involuntary creditors. This article's submission is more modest: the consensus about reform has been reached without taking account of certain of distribution regulation's most important practical effects. The ordering category of 'capital maintenance' has got in the way of a broader consideration of the regulation's effects and the distributional consequences of reform. 